

\section{Abstract}

This article aims to analyze the female representation authorship in Brazil's literary awards, the Jabuti Award, from 2000 to 2017 . We can say that in this period, $83 \%$ of the awardees are male-authorship works and $17 \%$ are female- authorship. From the survey and analysis of these data, we can affirm that male dominance prevails in literature, despite the evolution and of female empowerment. On the other hand, the positive point is that the works of female authorship winners have a narrative focused on the representation of women and denial of these established standards.

\section{Entradas para indexação}

PALAVRAS-CHAVE: Literatura. Prêmio Jabuti. Autoria feminina. Representatividade. KEYWORDS: Literature. Female authorship. Representation. Jabuti Award.

\section{Texto integral}

Historicamente, a luta feminina pela conquista do seu espaço em todos os âmbitos, principalmente no campo profissional, nunca teve tamanha proporção como nos últimos anos. Buscando seu lugar em uma sociedade dominada pelo masculino, é possível perceber várias conquistas s são o resultado de muitas reivindicações.

No campo literário não poderia ser diferente, após séculos de predominância masculina na escrita, tempos em que mulheres escreviam com pseudônimos masculinos para poderem fazer parte do mercado literário, em que homens escreviam sobre o universo feminino do ponto de vista deles, elas passaram a ocupar posição de destaque, ainda que isso tenha ocorrido aos poucos, por meio de muita luta. A busca pela representatividade, de poder falar sobre si e sobre sua visão do mundo, fez com que autoras antes oprimidas se destacassem, como é o caso da filósofa e intelectual Simone de Beauvoir, pioneira na escrita sobre a luta feminista através da publicação do livro de grande sucesso $O$ Segundo Sexo, de 1949.

Pensando sobre as reviravoltas da luta por reconhecimento e espaço, e considerando a literatura brasileira também como um universo predominantemente masculino, como pode ser observado no cânone da história da literatura (BOSI, 2000), além da grande notoriedade que o público feminino vem ganhando com o passar do tempo, no presente trabalho objetiva-se verificar como o texto literário da escritora mulher vem sendo reconhecido no meio literário. Além disso, questiona-se como ocorre o processo de representatividade na autoria feminina e como a escrita feminina é reconhecida através de um período de dezessete anos da maior premiação literária do Brasil, o Prêmio Jabuti. Para isso, pretendeu-se verificar a representação da voz feminina na categoria Romance do referido prêmio no período de 2000 a 2017. 
Nesse contexto, pode-se questionar qual a quantidade de escritoras mulheres que ganharam o prêmio Jabuti no período destacado e se estas escritoras já tinham - ou têm - uma trajetória de reconhecimento no campo literário. Além disso, é possível indagar se os livros escritos por essas mulheres possuem personagens femininas e como estas são abordadas.

Para isso, analisou-se a autoria feminina e o reconhecimento de obras escritas por mulheres na literatura brasileira contemporânea a fim de identificar se há vencedoras no principal prêmio da literatura brasileira, o Jabuti, na categoria Romance, no período de 2000 a 2017. Ainda, foram analisadas as obras vencedoras com o objetivo de identificar quais são os temas abordados, quem são os protagonistas e qual é a narrativa incorporada ao papel da mulher na trama.

No primeiro momento da pesquisa, de caráter bibliográfico, foram catalogadas as informações referentes às obras vencedoras na categoria Romance do Prêmio Jabuti, no período de 2000 a 2017. Dentre estas, destacaram- se as obras escritas por mulheres, para serem analisados os seguintes pontos: trajetória das escritoras, análise crítica das obras, tema, personagens principais, com o objetivo de reconhecer se elas escrevem sobre mulheres e como as descrevem.

\section{A mulher na história}

Em tempos em que o feminismo vem ganhando grande notoriedade, em que as mulheres defendem seus direitos de igual proporção aos do público masculino, é necessário que repensemos sobre como o trabalho dessas mulheres é - ou foi reconhecido. 0 público feminino está representado em todas as categorias profissionais, inclusive no campo literário, visando à representatividade cultural que esta área abrange e à possibilidade de falar sobre si e sobre o mundo com um olhar que lhe é próprio.

Numa área em que cada um busca seu espaço e oportunidade de ser ouvido, nos deparamos com distorções, principalmente causadas pela questão de gênero. Conforme destaca Beauvoir (1970), ser mulher na sociedade de extremo machismo significa estar em posição desfavorável, ser vassala e estar em condições inferiores às do homem:

Economicamente, homens e mulheres constituem como que duas castas; em igualdade de condições, os primeiros têm situações mais vantajosas, salários mais altos, maiores possibilidades de êxito que suas concorrentes recém-chegadas. Ocupam na indústria, na política etc, maior número de lugares e os postos mais importantes. Além dos poderes concretos que possuem, revestem-se de um prestígio cuja tradição a educação da criança mantém: o presente envolve o passado e no passado toda a história foi feita pelos homens. No momento em que as mulheres começam a tomar parte na elaboração do mundo, esse mundo é 
ainda um mundo que pertence aos homens (BEAUVOIR, 1970, p.21-22).

Ainda de acordo com a autora, apesar das várias reivindicações femininas por espaço ativo na sociedade, as conquistas só foram possíveis às mulheres quando os homens concederam. Ou seja, ainda que continuem a lutar por seus direitos, permanece sendo o sexo oposto que determina qual o papel que elas desempenham: "a ação das mulheres nunca passou de uma agitação simbólica; só ganharam o que os homens concordaram em lhes conceder; elas nada tomaram; elas receberam" (BEAUVOIR, 1970, p.13). Visto que o livro de Beauvoir foi publicado em 1949, percebe-se, mas ainda há muito a ser conquistado.

Para prosseguirmos, é necessário entendermos que a posição instaurada à mulher vai muito além de história e cultura. Biologicamente, as fêmeas da espécie humana foram condicionadas ao seu estado de reprodutora, e por isso consideradas, conforme afirmado por Beauvoir (1970), como escravas da espécie. Ao nascer mulher, trazemos na bagagem óvulos, menstruação, a função de gerar bebês, de alimentá-los e cuidá-los, porque, diferente de muitas outras espécies de animais, os bebês humanos são totalmente dependentes de outro alguém para que sobrevivam.

Em todo caso, por robustas que fossem as mulheres, na luta contra o mundo hostil as servidões da reprodução representavam para elas um terrível handicap: conta-se que as amazonas mutilavam os seios, o que significava que, pelo menos durante o período de sua vida guerreira, recusavam a maternidade. Quanto às mulheres normais, a gravidez, o parto, a menstruação diminuíam sua capacidade de trabalho e condenavam-nas a longos períodos de impotência (BEAUVOIR, 1970, p.82).

Assim como encontra- se, biologicamente em condição desfavorável ao macho da sua espécie, culturalmente o sexo feminino também é desdenhado (BEAUVOIR, 1970). Basta observar algumas das tradicionais falas de pais de meninos e de meninas, quando ordenam que elas "não sentem de pernas abertas", pois é "feio", mas, por outro lado, vangloriam o órgão sexual masculino. Sem sombra de dúvidas, nascer mulher ainda é estar em desvantagem, à mercê de adequada- se aos padrões sociais, de classificar suas ações em aceitáveis ou inaceitáveis para a sociedade a qual está submetida.

Em função disso, encontramos, na história da sociedade, séculos de atraso por ser necessário que mulheres desempenhassem apenas funções de esposa, reprodutora e cuidadora do lar. Deparamo-nos também com revolucionárias, que desafiaram sua "pré-condição", se destacando e mostrando que mulheres podem e devem ir além daquilo a que foram condicionadas. É nesse ponto que surgem os diversos movimentos feministas. 
No Brasil, o feminismo tomou grande proporção a partir de 1970, caracterizado como o marco da luta feminista brasileira. Ainda na referida década, mais precisamente em 1975, a ONU institui o Ano Internacional da Mulher, auxiliando na eclosão dos movimentos feministas no Brasil, visto que essas discussões na Europa e na América do Norte já estavam ganhando muita força.

Mesmo diante de tanta progressão, é necessário compreendermos que ainda há muito pelo que lutar. Enquanto a sociedade pressupor gêneros superiores e inferiores, precisamos nos questionar se categorizar é a solução. Tendo conhecimento das lutas feministas, é possível compreender que a intenção não é pôr a mulher acima do homem, mas sim garantir que ambos tenham seus direitos de forma igualitária.

\begin{abstract}
O que se procurou infatigavelmente provar foi que a mulher é superior, inferior ou igual ao homem. Criada depois de Adão, é evidentemente um ser secundário, dizem uns; ao contrário, dizem outros, Adão era apenas um esboço e Deus alcançou a perfeição do ser humano quando criou Eva; seu cérebro é o menor, mas é relativamente o maior; e se Cristo se fez homem foi possivelmente por humildade. Cada argumento sugere imediatamente seu contrário e não raro ambos são falhos... Se quisermos ver com clareza devemos sair desses trilhos; precisamos recusar as noções vagas de superioridade, inferioridade, igualdade que desvirtuam todas as discussões e reiniciar do começo (BEAUVOIR, 1970, p.21).
\end{abstract}

É possível, assim, compreendermos por que Simone de Beauvoir, já em 1949, sendo uma das pioneiras na escrita sobre o tema mulher e sobre a situação do feminismo na sociedade dominada por homens, afirmou a célebre frase "Ninguém nasce mulher: torna-se mulher" (BEAUVOIR, 1967, p.9). Em outras palavras, torna-se mulher a partir do questionamento do papel que desempenhamos na sociedade, da adesão de nossos direitos, principalmente de liberdade, do respeito, e do pensamento de que nossas atribuições como indivíduos não estão somente relacionadas com a função biológica de reproduzir.

\title{
A mulher na literatura
}

Da mesma forma que a mulher buscava reconhecimento e direitos semelhantes aos dos homens em diferentes contextos, na literatura não poderia ser diferente. Legitimada numa sociedade patriarcal, após anos de predominância masculina, lendo uma literatura que, na maioria das vezes, falava sobre as mulheres, porém escrita por homens, sentiu-se a necessidade de que elas ativassem suas vozes, incorporando no campo literário um pouco de si e podendo refletir sobre o mundo. Ao contrário de retraírem-se e permanecerem submissas à sociedade machista, mulheres se redescobriram para criar uma literatura feminina que fala sob seu ponto de vista, sob suas perspectivas, afinal, ninguém melhor para falar de mulher do que ela própria. 
O silêncio dos grupos marginalizados - entendidos em sentido amplo, como todos aqueles que vivenciam uma identidade coletiva que recebe valoração negativa da cultura dominante, sejam definidos por sexo, etnia, cor, orientação sexual, posição nas relações de produção, condição física ou outro critério - é coberto por vozes que se sobrepõem a ele, vozes que buscam falar em nome desses grupos, mas também, embora raramente, pode ser quebrado pela produção literária de seus próprios integrantes(DALCASTAGNÈ, 2005, p.15).

Porém, para chegarmos a esse ponto na literatura, muito trabalho teve que ser feito. Por se tratar de um grupo de pouca voz e reconhecimento, escritoras, no início de sua carreira, tiveram a necessidade de publicar seus trabalhos através de pseudônimos, pois a escrita feminina representava uma grande transgressão se comparado à função habitual estabelecida às mulheres. Um dos casos mais famosos é o da escritora Jane Austen, reconhecida mundialmente pelo clássico Orgulho e Preconceito, mas que no início de sua carreira precisou publicar suas obras de forma anônima para que houvesse interesse e adesão por parte dos leitores da época.

A marginalização dos grupos sociais considerados "inferiores" transformou sua expressão num discurso discriminado e censurado. Houve a necessidade de incorporar novos discursos, novas possibilidades, trazendo a perspectiva de haver uma sociedade em que as desigualdades são apresentadas de forma posicionada e que para refletir sobre elas e lutar contra as adversidades existe uma multiplicidade de vozes, devendo considerar, assim, cada lugar de fala (RIBEIRO, 2017). A visão de uma sociedade patriarcal e preconceituosa é de mulheres restritas, sentenciadas a serem devotadas às suas famílias, limitadas ao mercado de trabalho e de capacidade inferior ao sexo oposto.

(...) Séculos de literatura em que as mulheres permaneciam nas margens nos condicionaram a pensar que a voz dos homens não tem gênero e por isso existiam duas categorias, a "literatura", sem adjetivos, e a "literatura feminina", presa a seu gueto. Da mesma forma, aliás, que por vezes parece que apenas os negros têm cor ou somente os gays carregam as marcas de sua orientação sexual. Romper com essa estrutura de pensamento é muito mais difícil quando não se percebe, ou não se assume, que nosso olhar é construído, que nossa relação com o mundo é intermediada pela história, pela política, pelas estruturas sociais. E que, portanto, toda e qualquer apreciação literária é regida por interesses, por mais difusos que eles sejam (DALCASTAGNÈ, 2005, p. 64).

Muito contestada, a autoria feminina se manteve em constante crescimento graças à perseverança das mulheres em não desistir diante de críticas e relutância. Escrever um livro não significava apenas colocar palavras sobre algumas páginas, 
era trazer sua voz, agregar sentido e ter a intenção de que quem leria também o tornaria relevante. Ler uma história escrita por uma mulher foi edificante e necessário para que elas se reconhecessem, e outras criassem coragem e se expusessem para o mundo. Para tanto, ao tempo que as mulheres descobriam uma ferramenta para ativar suas vozes, a literatura escrita por homens continuou a se desenvolver, sobressaindo-se quantitativamente sobre as escritas femininas:

(...) Fica claro que a menor presença das mulheres entre os produtores se reflete na menor visibilidade do sexo feminino nas obras produzidas (...). A resposta talvez esteja na própria predominância masculina na literatura (e, imagina-se, em outras formas de expressão artística), que proporciona às mulheres um contato maior com as perspectivas sociais masculinas. Outra hipótese é que, diante dos avanços promovidos pelo feminismo, os homens se sentem cada vez mais "deslegitimados" para construir a perspectiva feminina (DALCASTAGNÈ, 2005, p. 36-37).

A produção literária constante, tanto na autoria masculina, quanto na feminina, trouxe também questionamentos sobre o que estava sendo disponibilizado aos leitores, de forma mais específica, considerando que as autoras investiram no mercado literário como uma forma de apoiar a luta feminina pelo seu espaço. Dalcastagnè, na pesquisa intitulada $A$ personagem do romance brasileiro contemporâneo: 1990-2004, dentre outras informações, apresenta dados sobre as personagens femininas em diversas obras da literatura brasileira escritas num período de 14 anos. Como já era de se esperar, a visão de uma mulher sem voz, sem atitude e devotada ao marido e ao lar é predominante na maioria das obras. Deparamo-nos com a continuidade de uma história escrita há anos por uma sociedade machista, que delimita o protagonismo ao homem.

O espaço das mulheres representadas no romance brasileiro contemporâneo é, sobretudo, o espaço doméstico. Nas últimas décadas, registrou-se um avanço - ainda insuficiente, mas indiscutível - na condição feminina. (...) a grande maioria das personagens masculinas são maduras, portanto plenamente incorporadas ao mercado de trabalho, a "incongruência" fica ainda mais evidente (DALCASTAGNÈ, 2005, p.39-40).

Para tanto, ao evoluirmos na autoria feminina na literatura brasileira, também foi preciso delimitar caminhos para incorporar a busca pela representatividade. Diante da literatura já escrita, com representações unilaterais da mulher, buscou-se apresentar uma visão mais próxima das mulheres com sonhos, metas e objetivos, com necessidades biológicas e pessoais, as quais foram incorporadas às narrativas.

A partir do momento em que as autoras percebem que a crítica não pode ser somente direcionada ao machismo existente e sim reescrever a importância do papel desempenhado pela própria mulher na busca por seus direitos é que a 
literatura escrita por elas passa a ter um objetivo fundamental, alinhando os discursos já existentes.

(...) tem-se que ao passo em que o movimento feminista foi avançando e se consolidando, igualmente a literatura de autoria feminina sofreu alterações. Passou de uma situação de reprodução de estereótipos machistas, para o questionamento acerca dessa condição da mulher(TOFANELO, 2015, p.04).

Diante dessas constatações, passa-se a analisar, no presente trabalho, a legitimação da autoria feminina na literatura brasileira, embasada pelo reconhecimento na categoria Romance do Prêmio Jabuti, no período entre os anos 2000 e 2017.

\section{Autoria masculina versus autoria feminina: coleta e análise dos resultados}

A etapa inicial do corpus da pesquisa foi a delimitação dos objetos a serem analisados. A partir de pesquisas sobre o Prêmio Jabuti, considerando categorias e espaço de tempo objetivado, decidiu-se escolher a categoria Romance em função de ser esta uma das mais importantes categorias da premiação. Dando seguimento, foram catalogadas todas as obras vencedoras da categoria Romance no espaço de dezessete anos, iniciando no ano 2000 até a última premiação em 2017.

\section{Panorama quantitativo das autorias}

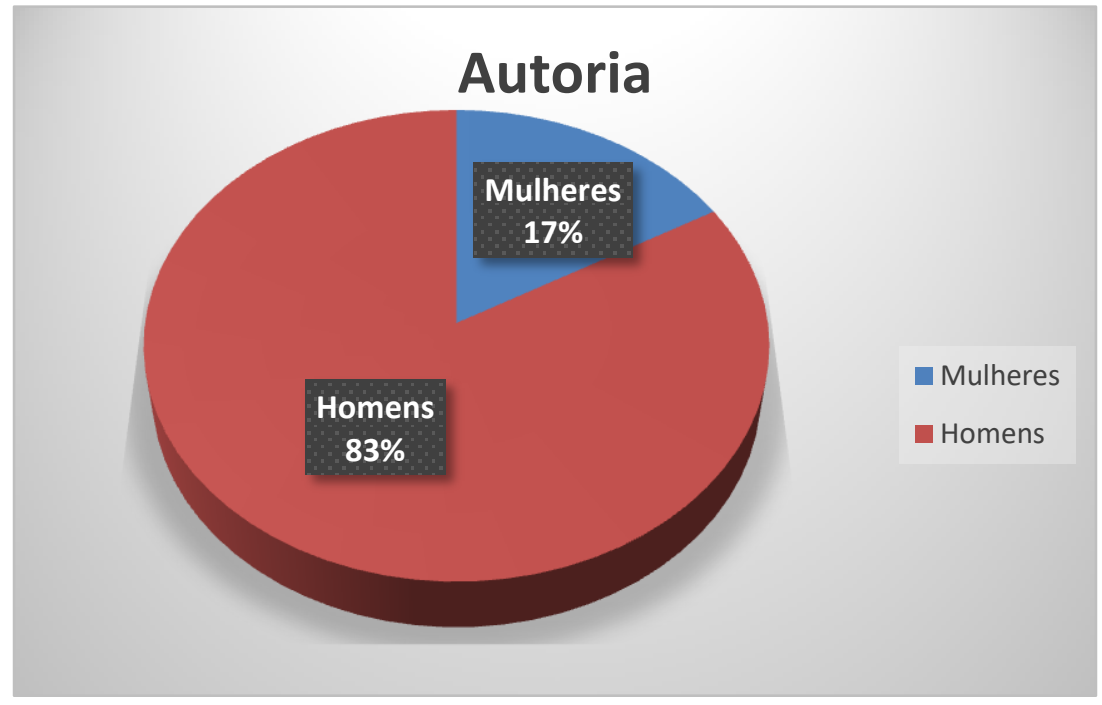

Gráfico 1: Percentual de autores homens e mulheres que receberam o prêmio Jabuti entre 2000 e 2017. 
Conforme pode ser observado no gráfico acima, das dezoito obras vencedoras, apenas três são de autoria feminina, sendo elas: em 2003, a obra Dias e Dias, de Ana Miranda; em 2005 a ganhadora foi Nélida Piñon com seu livro Vozes do deserto; e em 2015 a obra vencedora foi Quarenta dias, de Maria Valéria Rezende.

Um dos pontos também observados na pesquisa feita sobre a premiação nos últimos dezoito anos é em relação à carreira literária dos escritores e escritoras vencedores(as). Podemos verificar que as três autoras vencedoras possuem uma caminhada renomada no campo literário, com muitas obras escritas e publicadas e que renderam várias premiações e reconhecimento, como poderá ser observado no próximo subcapítulo deste trabalho. Com o sexo oposto não ocorre o mesmo, observa-se que uma parcela dos autores premiados possui menos de 10 obras publicadas, considerados jovens na escrita de romances, como é o caso do vencedor de prêmio em 2016 Julian Fucks com 4 romances publicados; Oscar Nakasato, vencedor em 2012 com seu primeiro e único romance publicado; e em 2010 o primeiro romance publicado por Edney Silvestre recebeu a premiação. Em relação às autoras vencedoras, das três, apenas Maria Valéria Rezende possuía três romances publicados quando recebeu seu prêmio em 2015.

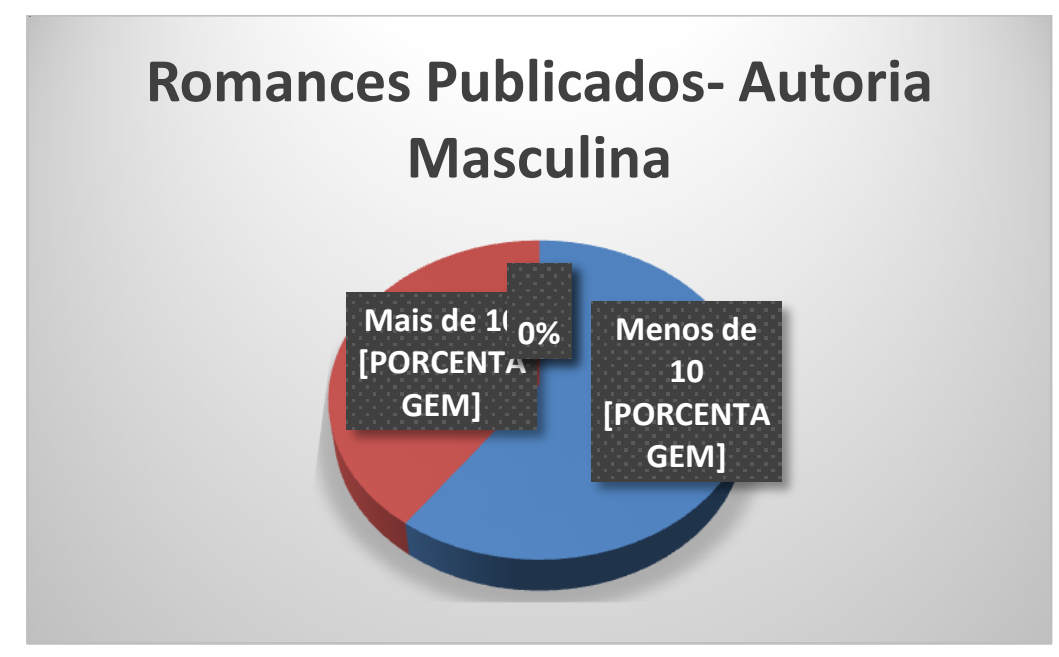

Gráfico 2: Quantidade de romances publicados por autores masculinos vencedores do Prêmio Jabuti: dos quinze analisados, sete possuíam menos de 10 obras publicadas até o ano de sua conquista. 


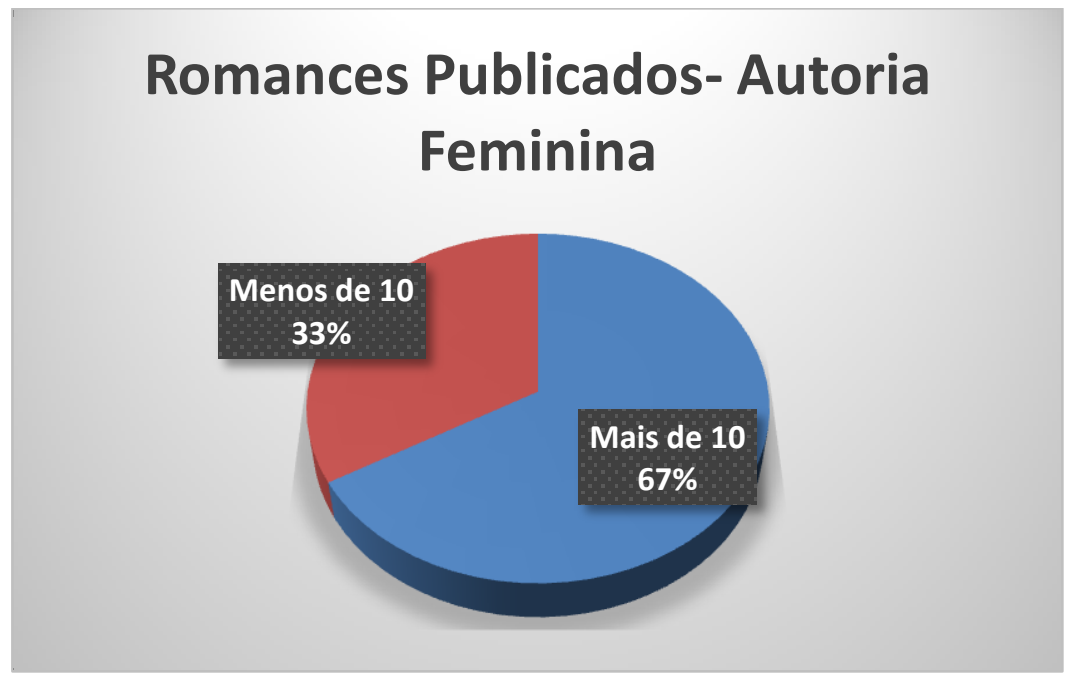

Gráfico 3: Quantidade de romances publicados por autoras femininas vencedores do Prêmio Jabuti: das três escritoras analisadas, apenas uma possuía menos de 10 obras publicadas até o ano de sua conquista.

Mulheres na categoria Romance do Prêmio Jabuti: 2000 a 2017

\section{3: Ana Miranda: Dias e Dias}

Com uma carreira conceituada na literatura, Ana Maria Nóbrega Miranda possui três prêmios Jabuti nas categorias Revelação Romance e Romance: em 1990, com Boca do Inferno (uma de suas principais e mais conhecidas obras), em 2003, com Dias e Dias, e em 2016, com a biografia Xica da Silva, a Cinderela Negra, além de outros tantos prêmios provindos de seus contos, crônicas, biografias e romances. Romancista, atriz e desenhista, possui mais de 50 livros publicados. Suas obras já foram traduzidas para mais de vinte idiomas. Além de receber prêmios por suas escritas, a autora também já foi reconhecida pelo seu trabalho no campo literário através do título de "Doutor Honoris Causa", recebido em 2015 pela Universidade Federal do Ceará.

Na obra Dias e Dias a autora utiliza uma de suas especialidades - escrever romances históricos - para nos levar ao mundo de Feliciana e do escritor Gonçalves Dias. O romance acontece no século XIX, na cidade de Caxias, no estado do Maranhão. Feliciana, protagonista narradora, é uma jovem vinda de uma família modesta nordestina que conta, em primeira pessoa, sua história desde a adolescência, quando teve o primeiro contato com Antônio Gonçalves Dias através dos poemas escritos por ele, por quem desenvolve um sentimento muito forte. De forma inocente, Feliciana nutre seu amor por Antônio em meio à pobreza, 
preconceito, entre outros empecilhos que fazem com que ambos não expressem seus sentimentos.

Sonhadora e obstinada, Feliciana revela através de sua narração detalhes de seu encantamento pelo escritor. Após ter acesso a cartas que Antônio escrevia e enviava a Alexandre Teófilo, seu grande amigo, Feliciana passa a sentir algo muito forte pelo escritor:

Pensava em Antônio, isso me enchia de uma estranha felicidade, ele estava sempre por perto pois vivia dentro de mim, pelo menos o seu fantasma, eu o via nas palavras, eu o ouvia no canto dos sabiás, no balouçar das palmas, em cismar sozinha à noite eu o via nas cortinas, nas nuvens e nas estrelas, via seu rosto estampado na lua, nos rostos dos rapazes de Caxias, no do professor Adelino, enquanto o professor Adelino olhava-me de esgueira eu pensava em Antônio, temia esquecer Antônio, não podia esquecê-lo, isso seria uma traição a mim mesma (...) (MIRANDA, 2002, p.53).

Além de relatar sua paixão pelo escritor, Feliciana traz um panorama do "ser mulher" no século XIX. Em muitas passagens da narrativa, nos deparamos com a preocupação da personagem em se tornar uma mulher semelhante às demais personagens femininas da época:

A vida que me esperava era a mesma vida de Natalícia, eu olhava os dias e dias da sua vida e sentia vontade de me desviar daquilo (...) Natalícia sempre se levantava para a ceia da meia-noite de papai, vinha do quarto sem um fio de cabelo fora do lugar, de chinela, servir a ceia, papai reclamava aperreado que a tapioca estava grossa, levantava da mesa, Natalícia saía para a cozinha a lavar pratos e a encontrar sujeiras deixadas por escravas, e só ia se baldear na rede lá pelas duas da madrugada, mas acordava às cinco para preparar o café de papai, Deus que me livrasse de uma vida dessa, como podia eu não querer vida diferente? (MIRANDA, 2002, p.53).

Além de trazer outros conhecimentos históricos, como a relação estabelecida entre Brasil e Portugal, a autora aborda várias relações de poder e inferioridade dos sexos. As mulheres são apresentadas como de donas de casa, dedicadas ao marido e aos filhos, devotadas ao bem-estar de suas famílias, ou como as moças que ficavam sempre à espera de encontrar um possível marido para construir suas famílias e ter a quem se dedicar:

(...) as moças da capital não aprendiam a cozinhar, ficavam o dia inteiro grudadas na janela esperando passar um sujeito distraído para o agarrar, sonhando ir para a rua, embaladas em sapatinhos de seda, os cabelos pelas nuvens, moças que quando conversavam 
era só para aprovar ou reprovar o noivo de uma que estava por casar, todas se remoendo de inveja, porque só pensavam em casar (...) (MIRANDA, 2002, p.63).

Feliciana, por outro lado, revela seu lado crítico quanto a essa prédisposição feminina às imposições machistas: "Porque casar é muito fácil, mas depois criar os filhos, e cuidar da casa! Tenham paciência!” (MIRANDA, 2002, p.63). Em uma das passagens da obra, Feliciana relata que, como já fizera quatorze anos, seu pai estava à procura de um noivo para ela, pois já era o momento em que devia casar. Mesmo não concordando com o casamento e com a escolha do noivo, a infeliz Feliciana se vê obrigada a ceder às ordens de seu pai:

Na data marcada, ao anoitecer no quarto vesti o vestido novo, soltei os cabelos, não sabia o que fazer, pintei o rosto de alvaiade e os lábios de carmim, olhando-me no espelho a buscar dentro de minh'alma aquela que eu era, Natalícia veio trançar meus cabelos e me viu com aquele rosto tão pálido, disse que eu estava parecendo uma defunta, eu disse que era isso mesmo, tinha acabado de morrer e ela estava vendo o meu defunto (...) (MIRANDA, 2002, p.73).

Ainda que por obrigação, a protagonista deixa transparecer aos demais personagens sua indiferença com o casamento e com as atitudes que uma mulher deveria ter, conforme as tradições da época. Faz deboches perante seu pai e noivo, assume que está insatisfeita com presentes e regalias que recebe.

Na obra de Ana Miranda, percebe-se a construção de uma personagem que, ao mesmo tempo em que desenvolve uma intensa paixão pelo escritor Gonçalves Dias, reflete sobre suas decisões e sobre o papel desempenhado pelas mulheres da sua sociedade. Percebe-se também a preocupação da protagonista em não se tornar submissa, de poder decidir sobre suas escolhas sem precisar tê-las determinadas pelos homens da sua família. Ao contrário de Natalícia, Feliciana tem conhecimento de que a sociedade na qual ela vive é regida pelo patriarcado, mas ao mesmo tempo, mesmo que de forma sutil, se questiona e procura maneiras de poder ser dona de si e de suas decisões.

\section{5: Nélida Piñon: Vozes no deserto}

Conhecida pelo valioso trabalho na literatura brasileira, Nélida Piñon possui uma trajetória de muitas conquistas no campo literário, entre elas, tornou-se a primeira mulher, em 100 anos, a presidir a Academia Brasileira de Letras, além de ter obtido prêmios nacionais e internacionais por reconhecimento de suas obras e por sua participação ativa no campo literário. 
Ganhou o prêmio Jabuti no ano de 2005 com a obra Vozes no Deserto na categoria Romance, um dos objetos de análise desta pesquisa. Vozes do Deserto narra uma nova perspectiva da obra As Mil e Uma Noites, na qual a autora utiliza a narrativa focada na principal personagem do romance: Scherezade.

A obra de Nélida Piñon reescreve a façanha de Scherezade na tentativa de acabar com o destino cruel dado às amantes de Califa. Além de reestruturar a tradicional obra de "As mil e uma noites" do ponto de vista da personagem, a autora traça uma linha de construção no desafio da arte de contar histórias. Scherezade é altruísta, com o dom de narrar histórias, e percebe que essa habilidade pode ser usada em prol de um propósito maior. Apesar de ter uma vida cômoda, filha de um vizir-servidor do Califa, fica perplexa com o desfecho dado às amantes de Califa, mortas logo após passarem a noite com ele. Dessa forma, ela planeja uma forma de redefinir o futuro das jovens escolhidas pelo Califa, utilizando a contação de histórias para vencê-lo.

Através da manipulação, Scherezade tece sua própria história, utilizando-se de recursos como as reviravoltas traçadas na história que conta ao Califa a fim de induzir a curiosidade do soberano para preservar sua vida por mais uma noite. Além de ter em mãos a responsabilidade de parar com as atrocidades cometidas pelo Califa com suas amantes, ela ainda precisa se manter concentrada para salvar sua vida, a de sua irmã e a da escrava, pois são suas cúmplices nessa corrida pela sobrevivência.

(...) em certas tardes duvida se terá ânimo de seguir frequentando o leito de Califa, de sujeitar-se aos seus caprichos. Quando se pergunta por que narra, hesita na resposta, e não lhe importa. Sabe apenas, até o momento, que narra com o intuito de afugentar a sombra das futuras vítimas do vingativo Califa projetada na plataforma, onde o cadafalso destaca-se, imponente (PIÑON, 2006, p. 233).

É através das diversas vozes que a rodeiam que a personagem consegue manipular Califa, fazendo com que ele a veja como uma figura indispensável. Ela produz nele um sentimento de dependência, pois para saber o desfecho da história, o Califa precisa da Scherezade. Em alguns momentos, podemos notar que o Califa percebe que sua prisioneira detém poder sobre ele, mas sua curiosidade é maior, então ele não concentra seus pensamentos sobre essa preocupação:

Apesar de tal propósito, tarda em encomendar a morte de Scherezade. Inquieta-o que use as histórias da jovem como pretexto para mantê-la ao seu lado. Admite, certamente, que a fantasia daquela contadora lhe azeita o corpo, e suas palavras, às vezes cultas, quase sempre de raiz popular, suspendem as noções que tivera até então de realidade. (PIÑON, 2006, p.133)

Na obra de Nélida Piñon, percebe-se que a personagem construída pela autora possui conhecimento do poder que tem em relação ao Califa através da 
contação de histórias. A autora traz um panorama antes desconhecido dessa personagem tão popular na literatura, agora com poder de persuasão e segura de suas decisões e objetivos. Mesmo trazendo a visão de personagens secundárias que, ao contrário de Scherezade, apenas aceitam suas posições e ficam à mercê das imposições sociais, o foco é na construção de uma mulher além de seu tempo, que desafia os preceitos da sociedade na qual faz parte, com voz e vontade de fazer.

\section{5: Maria Valéria Rezende: Quarenta Dias}

A paulistana Maria Valéria Rezende dedicou sua vida à carreira de religiosa na Congregação de Nossa Senhora - Cônegas de Santo Agostinho, atuando em várias cidades e estados no Brasil. Além da religião, graduou-se em Língua e Literatura Francesa e Pedagogia. Apaixonada pela escrita, iniciou na área literária em 2001 e construiu um concreto caminho de reconhecimento. Participa ativamente de causas sociais e tem na literatura uma porta para mostrar de forma criativa esses problemas. Recebeu três prêmios Jabuti: em 2009 com o livro No risco do caracol, na categoria infantil, em 2013 com Ouro dentro na cabeça, na categoria juvenil, e em 2015 na categoria Romance e Livro do Ano com a obra Quarenta Dias. Neste romance nos deparamos com a história de uma nordestina que teve sua vida transformada a partir de um pedido de sua filha para que ela se mudasse para o sul.

Narrada em primeira pessoa, somos apresentados à Alice, uma personagem que está acostumada com a vida que leva como aposentada, morando na mesma casa pela vida toda, no mesmo bairro, com um dia a dia pacato, até que é surpreendida com o pedido/ordem de sua filha para mudar-se para Porto Alegre a fim de cuidar do seu futuro neto (que ainda não havia sido gestado), em outra região, outro estado, com novas pessoas. É difícil para ela acostumar-se com a ideia de mudanças, porém cede, pois, como ela própria diz, "é papel de mãe": "O certo pra ela era que eu afinal, já tinha chegado ao fim da minha vida própria, agora o que me restava era reduzir-me a avó" (REZENDE, 2014, p.26).

É recorrente na obra a comparação que ela mesma faz com a Alice de Lewis Carroll, os devaneios, as aventuras e as idas e vindas de sua vida, principalmente quando cita as fugas de Alice de seu próprio mundo, pois não se encontra mais nele. A personagem de Rezende traça diversas rotas de fuga, porém a necessidade de estar à disposição de sua filha, como se fosse uma obrigação como mãe, a faz retornar do "país das maravilhas":

Ela não tinha culpa de nada, fui eu quem tive coragem de recomeçar a vida, de lhe dar um novo pai, que ela, a bem-dizer, nunca teve nenhum, não lhe dei irmãos (...) Disse que se eu não tivesse generosidade pra ajudá-la agora era melhor nem ter tido filha nenhuma, que eu me decidisse logo, se não ia ser tarde demais (REZENDE, 2014, p.27). 
Numa tentativa amedrontada de ser responsável por sua trajetória, Alice toma atitudes desesperadas para poder se encontrar com seu eu: "É egoísmo querer ter minha própria vida? (...) Eu tenho vergonha de ter cedido, estou lhe dizendo, vergonha!" (REZENDE, 2014, p.42). Para isso, a personagem parte numa missão de encontrar um desconhecido numa cidade inexplorada. É nessa fuga que a protagonista se reencontra, conforme relatado por ela ao seu companheiro fiel, o caderninho da Barbie. Nessa trajetória, ela pode se redescobrir, organizar seus pensamentos, perceber que existem tantas outras situações que são mais complexas que as dela. Deparou-se com pobreza, incertezas, abandono e solidão.

Em uma primeira leitura, pode-se observar na obra a construção de uma personagem em um primeiro momento sem expressão própria, dependente da opinião de outras pessoas e que prefere se dedicar aos outros a viver sua própria vida. Percebe-se na obra de Maria Valéria Rezende a elaboração de uma personagem subjetiva, que precisa se encontrar e dar espaço aos seus sentimentos para desenvolver um pensamento sobre si e sobre o mundo no qual ela vive. A autora constrói uma protagonista com atitudes e reflexões que a tornam uma mulher que confronta os preceitos da sociedade, uma personagem com conflitos internos, principalmente o de ser mãe, pois passa a maior parte da narrativa se questionando se fez seu papel de forma correta, o que a faz sair da sua área de conforto para se deixar ser levada pelas iniciativas e vontades do momento.

\section{A autoria feminina e seus paradigmas}

A análise da premiação literária enfocada permitiu construir uma reflexão sobre o posicionamento e o reconhecimento da autoria feminina no meio literário brasileiro a partir da sua principal premiação - o Jabuti - e da categoria mais ilustre - o Romance. Em meio a dezoito premiações, deparou-se com a presença de apenas três autoras premiadas. Mais preocupante é perceber que para receber essa premiação essas autoras já haviam traçado uma carreira de renome e de muitas publicações e titulações. Todavia, a autoria masculina não seguiu os mesmos passos, pode-se observar que alguns escritores receberam a premiação de seu primeiro livro publicado, como nos casos dos autores Edney Silvestre em 2010, com seu romance Se eu fechar os olhos agora, e de Oscar Nakasato, em 2012, com a obra Nihonjin.

Por seu turno, as obras vencedoras de autoria feminina trazem o posicionamento dessas escritoras em relação aos valores patriarcais: elas constroem personagens femininas como protagonistas de suas obras. Essas personagens se empoderam ao longo das narrativas em prol de um objetivo próprio ou de um objetivo comum para a sociedade. Em suma, as escritoras premiadas deram voz às mulheres também na ficção, legitimando, desse modo, seu lugar de fala (RIBEIRO, 2017).

Mesmo assim, é possível perceber que o mercado literário é predominantemente masculino, assim como o reconhecimento por meio de premiações na maioria das vezes é destinado a autores homens. 
Infelizmente os dados mostram uma realidade conhecida. Não subtraindo os méritos de cada autor, a diferença entre autoria masculina e autoria feminina preocupa, pois é possível perceber que o quesito gênero tem peso relevante também no mercado literário e no reconhecimento. Por outro lado, tem-se escritoras que falam sobre mulheres e apresentam sua representatividade mesmo diante dessas adversidades sociais.

\section{Considerações finais}

Conforme apresentado, o presente trabalho propôs analisar a autoria e escrita feminina na principal premiação literária brasileira no período de dezessete anos. Num panorama geral, pode-se observar a desproporcionalidade de obras femininas vencedoras quando comparadas às obras masculinas. No período analisado, das dezoito obras premiadas, apenas três são de autoria feminina. Além disso, por meio da análise da trajetória literária dos autores (as) vencedores (as), é possível perceber maior número de obras escritas pelas autoras, além de renome e carreira conceituada no campo literário. Da mesma forma, destaca-se o enfoque voltado à figura feminina abordado nas obras de autoria feminina premiadas.

A análise destacada neste trabalho reafirma algo que já é de conhecimento e também abordado por Beauvoir na obra Segundo Sexo, infelizmente convive-se com uma desigualdade de gênero que permeia todos os setores da sociedade. É possível questionar se os resultados encontrados nesta pesquisa e em outras tantas são frutos de uma sociedade patriarcal que sustenta um ideal de mulher arcaico ou se muitas vezes essa premissa faz com que estas se condicionem ao preconceito direcionado.

\section{Referências}

BEAUVOIR, Simone de. O segundo sexo: fatos e mitos. Rio de Janeiro: Difusão Europeia do Livro, 1970.

BEAUVOIR, Simone de. O segundo sexo: a experiência vivida. vol. 2. Rio de Janeiro: Difusão Europeia do Livro, 1967.

BOSI, Alfredo. História concisa da literatura brasileira. 37. ed. São Paulo: Cultrix, 2000.

CHEMIN, Beatris Francisca. Manual da Univates para trabalhos acadêmicos: planejamento, elaboração e apresentação. 3. ed. Lajeado: Editora Univates, 2015.

DALCASTAGNÈ, Regina. A personagem do romance brasileiro contemporâneo: 1990-2004. Brasília: Estudos de Literatura Brasileira Contemporânea, 2005.

MIRANDA, Ana. Dias e dias. São Paulo: Companhia das Letras, 2002.

PIÑON, Nélida. Vozes do deserto. Rio de Janeiro: Editora Record, 2006. 
REZENDE, Maria Valeria. Quarenta dias. Rio de Janeiro: Alfaguara, 2014.

RIBEIRO, Djamila. O que é lugar de fala? Belo Horizonte: Letramento; Justificando, 2017.

TOFANELO, Gabriela F. A trajetória do feminismo na literatura de autoria feminina brasileira: espaços e conquistas. Maringá: Anais do Simpósio Internacional de Educação Sexual, 2015.

ZOLIN, Lucia Osana. A literatura de autoria feminina brasileira no contexto da pósmodernidade. Juiz de Fora: IPOTESI, 2009.

\section{Para citar este artigo}

BACCON, Franciele Fátima; HAETINGER, Rosiene Almeida Souza. A representação da literatura escrita por mulheres no Prêmio Jabuti. Miguilim - Revista Eletrônica do Netlli, Crato, v. 9, n. 3, p. 719-735, set.-dez. 2020.

\section{As autoras}

Franciele Fátima Baccon é Graduada em Letras - Português e Literatura pela Universidade do Vale do Taquari (UNIVATES).

Rosiene Almeida Souza Haetinger é Doutoranda em Letras pela Universidade de Santa Cruz do Sul (desde 2017), mestra em Literatura Comparada pela Universidade Federal do Rio Grande do Sul (2008), especialista em Literatura Brasileira pela Universidade do Vale do Rio dos Sinos (2004) e licenciada em Letras pela Universidade de Santa Cruz do Sul (2002). Atualmente é professora da área de literatura da Universidade do Vale do Taquari (Univates). 